\title{
Pemeringkatan Cagar Budaya Tidak Bergerak
}

\author{
Syarif Achmadi \\ Balai Pelestarian Cagar Budaya Serang \\ Email : bp3serang@gmail.com
}

\begin{abstract}
Abstrak : Keanekaragaman cagar budaya Indonesia dapat mencerminkan kekayaan sekaligus identitas bangsa. Sebagai identitas bangsa, cagar budaya Indonesia jumlahnya belum diketahui secara pasti, termasuk di dalamnya jumlah cagar budaya yang termasuk peringkat lokal, peringkat regional, dan peringkat nasional. Hal ini terjadi karena instrumen untuk pemeringkatan cagar budaya belum tersedia.

Menyadari keterbatasan ini, maka makalah berjudul "Pemeringkatan Cagar Budaya Tidak Bergerak" dimaksudkan untuk memberi solusi terhadap permasalahan di atas. Tujuan pemeringkatan cagar budaya adalah melakukan penilaian/scoring terhadap cagar budaya guna membagi kewenangan pelestarian cagar budaya, dalam melakukan penilaian/scoring peringkat cagar budaya tidak bergerak menggunakan metode statistik. Langkah-langkah yang ditempuh terlebih dahulu adalah menentukan variabel apa saja yang akan dipelajari. Ada dua kategori variabel yang harus dibuat, yaitu variabel penyebab dan variabel akibat. Variabel penyebab dikenal dengan variabel bebas atau variabel faktor, sedang variabel akibat adalah variabel terikat (respons).

Keseluruhan variabel bebas sebanyak 15 variabel. Adapun keseluruhan variabel respon sebanyak 45 variabel. Berdasarkan skala interval, peringkat 0 merupakan peringkat yang tidak ada nilainya (nol nilai mutlak/bukan cagar budaya). Peringkat 1 merupakan peringkat kabupaten/kota yang nilainya antara 16,5 \% - $33 \%$. Peringkat 2 merupakan peringkat regional yang nilainya 33,5 \% - 66\%. Adapun peringkat 3 merupakan peringkat nasional yang nilainya $66,5 \%-100 \%$.

Peringkat lokal dapat naik menjadi peringkat regional bahkan peringkat nasional. Demikian juga peringkat nasional dapat turun peringkat menjadi peringkat regional, peringkat lokal, bahkan tidak masuk dalam peringkat cagar budaya. Berdasarkan penjelasan di atas dapat disimpulkan, bahwa peringkat cagar budaya bersifat dinamis, artinya sewaktu-waktu dapat berubah baik turun peringkat maupun naik peringkat. Semua ini tergantung pada kondisi eksisting cagar budaya terkini.
\end{abstract}

Kata Kunci : Cagar budaya tidak bergerak, peringkat, dinamis

Abstract : A variety of Indonesian cultural heritage can reflect wealth and nation identity. As nation identity, the number of Indonesian cultural heritage, moreover the number of cultural heritage that belongs to local rank, regional rank, and national rank doesn't known surely. It's because the instrument to rank cultural heritage doesn't available for today.

In realizing this limitedness, this paper "The Ranking Unmovable Cultural Heritage" is intend to give solution from the problems above. The aim of this paper is also to give a score for in order to divided an authority of cultural heritage conservation.

Statistical method is being use to scoring unmovable cultural heritage. The first step is to know variable that will be learned. There are cause variable and consequence variable. A cause variable is known free variable or factor variable. Even a consequence variable is known as a bounded variable.

The totals of free variable are 15 and all of respond variables are 45 . Based on interval scale, 0 is the rank that has no score (not unmovable cultural heritage). The first rank is local level; it has score between $16.5 \%-33 \%$. The second rank is regional level; it has score between $33.5 \%-66 \%$. The last, the third rank is national level; it has score between $66 \%$ - 100\%.

The local level can be ascend to be regional level or national level. Never theless the national level can be descend to regional level, local level or turn to be zero score which is take out from the cultural heritage list. Based on the explanation above, the rank of cultural heritage is dynamic. It means that the level can be ascend or descend. All of this depends on the situation of cultural heritage in present.

Keyword: unmovable cultural heritage, rank, dynamic

\section{Latar Belakang}

Keanekaragaman budaya Indonesia berupa tinggalan budaya yang bersifat non-fisik (intangible) dan tinggalan budaya fisik (tangible). Tinggalan budaya sering dimaknai atau ditafsirkan sebagai identitas bangsa Indonesia sekaligus sebagai aset bangsa yang penting dan sangat berharga. Undang- 
Undang RI No. 11 Tahun 2010 tentang Cagar Budaya mengatur pembagian kewenangan antara pemerintah pusat, provinsi, dan kabupaten/ kota. Cagar budaya yang termasuk peringkat nasional dan internasional tetap menjadi tanggung jawab dan kewenangan pemerintah pusat, adapun cagar budaya yang memiliki peringkat provinsi atau kabupaten/kota diserahkan kewenangannya ke daerah sesuai dengan tingkatannya (Undang-Undang No. 11 Tahun 2010).

Pemeringkatan cagar budaya merupakan kewajiban yang harus dilaksanakan sebagaimana diamanatkan pada pasal 41, berbunyi "Pemerintah dan Pemerintah Daerah dapat melakukan pemeringkatan Cagar Budaya berdasarkan kepentingannya menjadi peringkat nasional, peringkat provinsi, dan peringkat kabupaten/kota berdasarkan rekomendasi Tim Ahli Cagar Budaya” (Undang-Undang No. 11 Tahun 2010).

Tim ahli cagar budaya dibentuk untuk menentukan peringkatan cagar budaya yang ditetapkan oleh gubernur, bupati/ walikota, dan atau menteri. Tim ahli cagar budaya, adalah kelompok pelestari yang terdiri atas tenaga ahli pelestarian dari berbagai bidang ilmu dan telah memiliki sertifikasi kompetensi untuk memberikan rekomendasi penetapan, pemeringkatan, dan penghapusan cagar budaya. Tenaga ahli pelestarian merupakan orang yang karena kompetensi keahlian khususnya dan/ atau memiliki sertifikasi di bidang pelindungan, pengembangan, atau pemanfaatan cagar budaya (Undang-Undang No. 11 Tahun 2010).

Pemeringkatan cagar budaya memerlukan seperangkat instrumen yang dapat membedakan cagar budaya termasuk dalam peringkat lokal, regional, atau nasional. Berkaitan dengan itu, maka maksud pemilihan judul Pemeringkatan Cagar Budaya adalah untuk membuat pedoman pemeringkatan cagar budaya, dalam hal ini dibatasi pada cagar budaya tidak bergerak. Adapun tujuannya adalah sebagai acuan dalam melakukan scoring cagar budaya berdasarkan kondisi eksisting.

Fenomena yang diteliti harus didefinisikan terlebih dahulu untuk dapat mempelajari dan memahami fenomena tersebut. Fenomena yang dimaksud adalah menentukan variabel-variabel dan bagaimana cara mengukurnya. Pengukuran adalah dasar dari penyelidikan ilmiah. Analisis yang dilakukan dimulai dengan pengukuran objek yang akan dipelajari. Pengukuran adalah pemberian angka atau kode pada suatu objek.Terdapat empat jenis skala pengukuran yaitu nominal, ordinal, interval, dan ratio. Skala yang paling rendah adalah nominal dan yang tertinggi adalah skala rasio. Skala pengukuran yang lebih tinggi akan memiliki karakteristik skala pengukuran di bawahnya. Misalnya, skala rasio akan memiliki karakteristik nominal, interval, dan ordinal.

Sebagai contoh fenomena di bidang pertanian. Sewaktu berkunjung ke situs Gunung Padang, kita akan melewati lembah, bukit, dan dapat menyaksikan pertumbuhan beberapa tanaman. Pada lokasi tertentu ada tanaman yang tumbuh dengan subur dan kurang subur. Pertanyaannya adalah, mengapa tanaman yang tumbuh di tanah tersebut ada yang tumbuh dengan subur, sementara di tempat lainnya tidak demikian. Setelah diperhatikan dengan seksama, ternyata pada lokasi yang tanamannya tumbuh dengan subur banyak mengandung bahan organik yang berasal dari pupuk kandang. Lalu disimpulkan bahwa tanaman subur karena tersedianya unsur hara yang cukup dari pupuk kandang. Pertanyaan selanjutnya adalah apakah semua jenis pupuk kandang pengaruhnya sama terhadap pertumbuhan tanaman? (Gunawan, F : 2010).

Demikian juga ketika diadakan kunjungan ke cagar budaya tidak bergerak, ternyata ada cagar budaya tidak bergerak desainnya unik dan ada cagar budaya tidak bergerak yang desainnya sederhana. Pertanyaannya adalah, mengapa ada cagar budaya tidak bergerak yang desainnya unik dan ada cagar budaya tidak bergerak yang desainnya sederhana. Berdasarkan informasi dan literatur, cagar budaya tidak bergerak yang desainnya unik merupakan cagar budaya nasional. Lalu disimpulkan, bahwa pada cagar budaya tidak bergerak yang desainnya unik masuk dalam kategori situs nasional. Pertanyaan selanjutnya adalah apakah semua cagar budaya tidak bergerak yang desainnya unik merupakan cagar budaya nasional?

Untuk mempelajari perbedaan peringkat cagar budaya tidak bergerak terlebih dahulu harus membuat 
Tabel 1. Variabel pengukuran peringkat cagar budaya

\begin{tabular}{|c|c|c|c|c|}
\hline NO & VARIABEL BEBAS & & VARIABEL TERIKA & \\
\hline \multirow{3}{*}{1} & Kepemilikan & Negara & Masyarakat adat & Individu \\
\hline & Cara Perolehan & Pencarian & Pengalihan & Penemuan \\
\hline & Registrasi & Penetapan & Rekomendasi & Pendaftaran \\
\hline \multirow{3}{*}{2} & Penyelamatan & Insitu & Pindah sebagian & Pindah total \\
\hline & Zonasi & Pengembangan & Penyangga & Inti \\
\hline & Umur & Absolut & Relatif & Arti kusus \\
\hline \multirow{3}{*}{3} & Pemeliharaan & Perawatan & Konservasi & Pembersihan \\
\hline & Pengamanan & Jupel/Polsus & Sarana pelindung & Partisipasi publik \\
\hline & Pengembangan & Ideologi & Akademi & Ekonomi \\
\hline \multirow{3}{*}{4} & Pemugaran & Restorasi & Rekonstruksi & Rehabilitasi \\
\hline & Revitalisasi & Informasi kuat & Fungsi ruang tetap & Budaya \\
\hline & Adaptasi & Menambah fasilitas & Fungsi ruang berubah & Fasad arsitektur tetap \\
\hline \multirow{3}{*}{5} & Pemanafaatan & Dokumentasi & Alih fungsi & Perbanyak \\
\hline & Pendanaan & APBN/APBD & Pemanfaatan & Sumber lain \\
\hline & Pengawasan & Koordinasi & PPNS & Masyarakat \\
\hline
\end{tabular}

variabel apa saja yang akan dipelajari. Dari gambaran di atas tampak bahwa ada dua kategori variabel yang harus dibuat, yaitu variabel penyebab dan variabel akibat. Variabel penyebab dikenal dengan variabel bebas atau faktor, dan variabel akibat adalah variabel terikat (respons).

Variabel peringkat cagar budaya tidak bergerak merujuk pada Undang-Undang Nomor 11 Tahun 2010 tentang Cagar Budaya. Variabel bebas (faktor) terdiri dari: kepemilikan, cara perolehan, registrasi, penyelamatan, zonasi, umur, pemeliharaan, pengamanan, pengembangan, pemugaran, revitalisasi, adaptasi, pemanafaatan, pendanaan, dan pengawasan.

Adapun variabel terikat (respon) terdiri dari: negara, masyarakat adat, individu, pencarian, pengalihan, penemuan, penetapan, rekomendasi, pendaftaran, insitu, pindah sebagian, pindah total, pengembangan, penyangga, inti, absolut, relatif, arti khusus, perawatan, konservasi, pembersihan, jupel/polsus, sarana pelindung, partisipasi publik, ideologi, akademi, ekonomi, restorasi, rekonstruksi, rehabilitasi, informasi kuat, fungsi ruang tetap, budaya, menambah fasilitas, fungsi ruang berubah, arsitektur tetap, dokumentasi, dan alih fungsi. Selengkapnya periksa Tabel 1.

\section{PEMBAHASAN}

Setelah menentukan variabel-variabel tersebut, langkah selanjutnya adalah menentukan cara pengukurannya. Untuk menentukan cara mengukur peringkat cagar budaya tidak bergerak, UndangUndang Nomor 11 tahun 2010 tentang Cagar Budaya pasal 42 harus dirujuk. Dari isi pasal di atas, maka indikator atau parameter yang digunakan dalam menentukan peringkat cagar budaya tidak bergerak adalah pemersatu, adiluhung, kawasan/lansekap budaya, ruang khas tradisional, evolusi peradabaan/ pertukaran lintas budaya.

Selengkapnya pasal 42 berbunyi, "Cagar budaya dapat ditetapkan menjadi cagar budaya peringkat nasional apabila memenuhi syarat sebagai berikut:

a. Wujud kesatuan dan persatuan bangsa.

b. Karya adiluhung yang mencerminkan kekhasan kebudayaan bangsa Indonesia.

c. Cagar Budaya yang sangat langka jenisnya, unik rancangannya, dan sedikit jumlahnya di Indonesia.

d. Bukti evolusi peradaban bangsa serta pertukaran budaya lintas Negara dan lintas daerah, baik yang telah punah maupun yang masih hidup di masyarakat dan/atau.

e. Contoh penting kawasan permukiman tradisional, lansekap budaya, dan/atau pemanfaatan ruang bersifat khas yang terancam punah”.

Kepemilikan oleh masyarakat adat secara kuantitas lebih banyak dibanding kepemilikan oleh Negara. Adapun kepemilikan individu/perorangan jumlahnya tidak terbatas. Pengelolaan dan pelestarian 
cagar budaya milik Negara atau masyarakat adat masih memungkinkan dipantau, sedang cagar budaya yang dimiliki individu/perorangan lebih sulit dipantau.

Cara perolehan melalui pencarian mendapat nilai tertinggi karena pencarian merupakan proses penemuan yang harus menempuh berbagai persyaratan dan ketentuan, serta harus didukung SDM yang kompeten. Pencarian berarti secara fisik cagar budaya belum riil. Pengalihan berarti secara fisik cagar budaya sudah ada, kemudian terjadi pemindahan kepemilikan. Adapun penemuan berarti semula cagar budaya tidak ada, tanpa sengaja atau secara kebetulan tanpa upaya mencari kemudian menjadi ada.

Jumlah cagar budaya dapat diketahui dengan melakukan registrasi. Proses registrasi melalui tahap pendaftaran, penelitian tim ahli yang menghasilkan rekomendasi dan penetapan. Cagar budaya yang sudah ditetapkan secara yuridis punya kekuatan hukum kuat. Memperhatikan prosesnya, maka nilai tertinggi adalah penetapan, karena penetapan sudah melalui proses penilaian dan rekomendasi. Rekomendasi mempunyai nilai lebih rendah karena merupakan tindak lanjut tahap pendaftaran. Adapun pendaftaran merupakan tahap awal untuk melakukan klasifikasi suatu objek termasuk cagar budaya dan bukan cagar budaya.

Penyelamatan adalah upaya untuk mempertahankan keaslian semaksimal mungkin. Keaslian menyangkut 4 hal, yakni bahan, bentuk, tata letak, dan teknik pengerjaan. Penyelamatan insitu tingkat keasliannya masih tinggi meski kemungkinan ada perubahan sebagai akibat dari upaya mempertahankan keberadaan cagar budaya. Penyelamatan dengan cara memindahkan sebagian, tingkat kerusakan terhadap keaslian lebih besar dibanding penyelamatan insitu. Adapun penyelamatkan dengan cara dipindahkan seluruhnya karena dalam kondisi terpaksa, sehingga jika tidak dipindahkan dapat menyebabkan cagar budaya tersebut musnah. Penyelamatan dengan cara ini yang dapat dipertahankan adalah keaslian bahan, sedang keaslian lain hanya rekayasa.

Bentuk pengamanan lain yang berkaitan cagar budaya adalah zonasi. Zonasi menyangkut tiga hal, yakni zona yang langsung berkaitan dengan keberadaan cagar budaya atau disebut zona inti. Berbatasan langsung dengan zona inti, dibuat zona penyangga. Dengan kata lain, zona penyangga baru dapat dibuat jika sudah ada zona inti. Zona penyangga dibuat karena kemungkinan masih ada sebaran cagar budaya yang belum ditemukan. Selanjutnya zona pengembangan dibuat setelah zona inti dan zona penyangga terbentuk. Berdasarkan tingkat pengamanannya, maka cagar budaya yang memiliki zona inti, penyangga, dan pengembangan paling terjamin pelestariannya. Cagar budaya yang memiliki zona inti dan penyangga tingkat pelestariannya akan lebih baik, sedangkan cagar budaya yang hanya memiliki zona inti, tingkat keterancamannya paling tinggi.

Penentuan umur dapat dibedakan menjadi tiga. Pertama umur yang nilainya mutlak atau dapat dipastikan. Cara memastikan umur absolute dapat melalui sumber tertulis, prasasti, atau carbon dating. Penentuan umur relatif dapat dilakukan dengan cara komparatif berdasarkan misalnya masa gaya. Adapun penentuan umur jika tidak dapat ditempuh berdasarkan absolut dan relatif, maka dapat didasarkan pada anggapan masyarakat karena cagar budaya tersebut mempunyai arti tertentu.

Pemeliharaan dapat berupa perawatan, konservasi, dan pembersihan. Pemeliharaan dengan cara pembersihan cukup dilakukan dengan alat dan cara yang sederhana, serta SDM tidak perlu mendapat keahlian khusus. Biasanya pemeliharaan cagar budaya tidak bergerak dilakukan oleh juru pelihara. Pemeliharaan dengan cara konservasi dilakukan karena pembersihan manual sudah tidak efektif. Untuk itu diperlukan penanganan khusus yakni konservasi. Kegiatan konservasi memerlukan keahlian khusus dan hanya dapat dilakukan dibawah pengawasan ahli konservasi. Perawatan dilakukan terhadap cagar budaya yang telah ditata pertamanannya. Hal ini karena perawatan bukan saja terhadap cagar budaya tetapi juga lingkungannya.

Pengamanan dimaksud agar cagar budaya aman dari gangguan manusia, alam, dan binatang. Pengamanan dengan cara penempatan juru pelihara/ polsus merupakan tindakan yang menjamin keberadaan cagar budaya. Tupoksi juru pelihara 
adalah merawat sekaligus informan jika terjadi ancaman dan memberi penjelasan tentang cagar budaya terkait. Adapun juru pelihara dilengkapi dengan pengetahuan khusus yang dapat menjamin pelestarian cagar budaya.

Pembuatan sarana pelindung adalah upaya untuk melindungi cagar budaya dengan menambah fasilitas baru, misalnya pemagaran, pembuatan cungkup, turap, dll. Untuk kedua jenis pengamanan ini masih terkontrol oleh UPT/dinas terkait. Sedangkan pengamanan berdasarkan partisipasi publik masih memiliki potensi ancaman, mengingat masyarakat mempunyai keinginan dan tujuan yang belum tentu sejalan dengan upaya pelestarian.

Pengembangan cagar budaya bertujuan untuk kepentingan ekonomis, akademis, dan kepentingan ideologis. Pengembangan untuk kepentingan ekonomi rawan terjadi perubahan/penurunan kualitas dan nilai. Seringkali karena tuntutan ekonomi cagar budaya dan lingkungannya diubah untuk memenuhi kebutuhan sesaat. Kepentingan akademis seringkali hanya meghasilkan konsepkonsep yang belum tentu operasional. Hal ini terjadi karena penekanan akademis lebih kearah disiplin keilmuan. Kepentingan ideologis adalah pengembangan yang ideal. Pengembangan ideologis, selain mempertahankan cagar budaya semaksimal mungkin, juga berupaya menggali dan mengungkap kearifan lokal/nilai yang dibutuhkan dalam rangka membangun kebanggaan dan jati diri bangsa.

Pemugaran cagar budaya bertujuan untuk mengembalikan ke bentuk semula berdasarkan keaslian dan melakukan perkuatan jika diperlukan. Pengembalian ke bentuk semula yang paling ringan baik tingkat kerusakan, biaya, sumberdaya manusia, dan waktu pelaksanaan adalah melakukan rehabilitasi. Dalam rehabilitasi hanya dilakukan perbaikan-perbaikan yang tidak berkaitan dengan perkuatan struktur. Pengembalian ke bentuk semula melalui rekonstruksi bobotnya lebih berat dibanding rehabilitasi, karena kerusakan ini penanganannya dapat bersifat konstruksi dan/atau struktural. Adapun restorasi merupakan pemugaran yang sesungguhnya.

Dalam kegiatan restorasi, selain kerusakan struktural, kerusakan konstruksi, juga diikuti penataan. Perbedaan mendasar antara restorasi dengan yang lain adalah pada kegiatan restorasi diawali dengan kegiatan studi kelayakan, studi teknis, bahkan master plan (jika dianggap perlu). Pada tahap pelaksanaan dilakukan pembongkaran dan pemasangan kembali, serta diikuti penataan lingkungan. Sedang rehabilitasi dan rekonstruksi kadang tidak didahului studi, serta proses bongkar dan pasang hanya dilakukan pada bagian yang akan diperbaiki saja.

Revitalisasi merupakan upaya untuk meningkatkan dan menumbuhkan kembali nilainilai penting cagar budaya. Dalam pelaksanaannya pembobotan revitalisasi dilakukan berdasarkan nilainilai penting budaya. Tidak tertutup kemungkinan objek cagar budaya sudah tidak asli lagi karena sesuatu hal, tetapi nilai penting yang berkaitan dengan cagar budaya itu sendiri masih hidup di tengahtengah masyarakat pendukungnya. Revitalisasi lain berupa perubahan pada objek cagar budaya karena sesuatu hal, akan tetapi tidak menyebabkan fungsi ruang berubah. Adapun revitalisasi yang tetap mempertahankan keaslian objek cagar budaya mempunyai bobot yang tinggi, sehingga revitalisasi itu sendiri justru menguatkan informasi tentang nilainilai penting cagar budaya.

Adaptasi merupakan pengembangan objek cagar budaya dengan melakukan beberapa penyesuaian. Adaptasi ada yang menyebabkan atau hanya mempertahankan bentuk muka/fasad arsitektur tetap. Bobot/nilai cagar budaya yang demikian rendah, karena hanya meninggalkan sisa dari keaslian. Adaptasi kedua yakni tuntutan kebutuhan ruang sehingga fungsi ruang diubah. Perubahan ini terjadi di dalam, sehingga secara keseluruhan tampak luar cagar budaya masih tetap seperti semula, sementara di bagian dalam telah mengalami perubahan.

Adapun adaptasi yang maksimal mempertahankan keaslian cagar budaya adalah dengan menambah fasilitas. Penambahan fasilitas cenderung tidak signifikan terhadap perubahan cagar budaya, misalnya pemasangan pendingin ruangan (AC), pembuatan taman, dll. Dengan demikian bobot cagar budaya tetap tinggi, karena tingkat perubahannya rendah. 
Pemanfaatan dapat dilakukan dengan cara perbanyakan, alih fungsi, dan dokumentasi. Pemanfaatan dengan cara perbanyakan sangat rentan terhadap cagar budaya itu sendiri. Kegiatan perbanyakan dapat mengakibatkan kerusakan objek cagar budaya, terjadi pemalsuan dan hal-hal lain yang menyebabkan cagar budaya mengalami degradasi. Pemanfaatan dengan cara pengalihan fungsi juga dapat berdampak pada perubahan keaslian cagar budaya.

Biasanya dalam pelaksanaannya, karena tuntutan fungsi baru mengharuskan ada perubahan pada cagar budaya. Misalnya bangunan tempat tinggal diubah menjadi café, maka dapat dipastikan akan dilakukan perubahan yang belum tentu sesuai dengan prinsip keaslian cagar budaya. Meski kemungkinan ada perubahan, tetapi dibanding dengan duplikasi dampaknya relatif lebih rendah. Adapun pemanfaatan dengan cara dokumentasi merupakan pemanfaatan yang paling kecil dampaknya terhadap keterancaman cagar budaya. Dengan kata lain cagar budaya tetap terjaga keasliannya.

Pelestarian cagar budaya tidak terlepas dari pendanaan. Sumber pendanaan itu ada yang berasal dari sumber lain, pamanfaatan, dan APBN/ APBD. Sumber dana yang berasal dari sumber lain biasanya bersifat tidak tetap baik jumlah maupun waktunya. Pelestarian dengan sumber dana seperti ini menyebabkan ketidakpastian keberlangsungan pelestarian cagar budaya. Biaya pelestarian yang berasal dari pemanfaatan bersifat rutin, sehingga upaya pelestariannya lebih terjamin. Adapun biaya pelestarian yang bersumber dari dana APBN/APBD lebih optimal untuk melakukan pelestarian, meski jumlahnya masih terbatas.

Pengawasan dapat dilakukan oleh masyarakat, PPNS, maupun melalui koordinasi. Pengawasan oleh masyarakat kadang dilatarbelakangi kepentingan tertentu bahkan berbeda dengan upaya pelestarian. Meski demikian sisi positifnya ada, hanya saja perlu dilakukan klarifikasi/pengecekan. Pengawasan oleh PPNS biasanya dilakukan jika terjadi tindak pelanggaran.Tugas PPNS memastikan bahwa tindak pelanggaran itu secara yuridis dapat diproses atau tidak. Adapun pengawasan melalui koordinasi merupakan pengawasan optimal, karena melibatkan banyak pihak, baik antar instansi pemerintah, aparat, tokoh, maupun masyarakat. Dari tiga macam pengawasan, maka bobot pengawasan yang paling rentan adalah pengawasan masyarakat, bobot sedang pengawasan oleh PPNS, dan bobot pengawasan maksimal adalah koordinasi.

\subsection{Variabel Nominal/Skala Nominal}

Variabel nominal merupakan variabel dengan skala pengukuran yang paling rendah tingkatannya dan hanya bisa digunakan untuk klasifikasi kualitatif atau kategorisasi. Artinya, variabel tersebut hanya dapat diukur dari segi apakah karakteristik suatu objek bisa dibedakan dari karekateristik lainnya, tetapi tidak dapat diukur atau bahkan mengurutkan peringkat kategori tersebut (Hasan, 2005).

Skala nominal hanya bisa memberikan kode/ label pada karakteristik tersebut, misalnya angka 1 untuk persatuan, angka 2 untuk adiluhung, angka 3 untuk kawasan/lansekap budaya/ruang khas tradisional, struktur, angka 4 untuk unik rancangannya/langka/jumlahnya terbatas, angka 5 untuk evolusi peradaban/pertukaran lintas budaya. Kode/label angka tersebut bisa saja ditukar. Kode ini hanya berfungsi sebagai pembeda antara kelima objek dan tidak menunjukkan urutan atau kesinambungan. Angka 2 tidak menunjukkan lebih tinggi atau lebih baik dibanding 1 dan seterusnya.

\subsection{Variabel Ordinal/ Skala Ordinal}

Variabel ordinal memungkinkan kita untuk mengurutkan peringkat dari objek yang kita ukur. Dalam hal ini kita bisa mengatakan A "lebih baik“ dibanding B atau B "kurang baik" dibanding A, namun kita tidak bisa mengatakan seberapa banyak lebihnya A dibanding B. Dengan demikian, batas satu variasi nilai ke variasi nilai yang lain tidak jelas, sehingga yang dapat dibandingkan hanyalah apakah nilai tersebut lebih tinggi, sama, atau lebih rendah daripada nilai yang lain, namun tidak bisa mengatakan berapa perbedaan jarak (interval) diantara nilai-nilai tersebut (Hadi,1987).

Variabel cagar budaya tidak bergerak akan diberi nilai 1, 2, dan 3. Cagar budaya yang nilainya 3 lebih baik dibanding cagar budaya yang nilainya 2 . 
Demikian juga Cagar budaya yang nilainya 2 lebih baik dibanding cagar budaya yang nilainya 1 . Akan tetapi batas dari variabel nilai tersebut tidak jelas, terdapat perbedaan jarak diantara nilai-nilai tersebut. Selengkapnya periksa Tabel 2.

\subsection{Variabel Interval/ Skala Interval}

Variabel interval tidak hanya untuk mengklasifikasikan, mengurutkan peringkatnya, tetapi juga bisa mengukur dan membandingkan ukuran perbedaan di antara nilai. Sebagai contoh, suhu yang diukur dalam derajat Fahrenheit atau Celcius merupakan skala interval. Kita dapat mengatakan bahwa suhu 50 derajat lebih tinggi dibandingkan suhu 40 derajat, demikian juga suhu 30 derajat lebih tinggi dibanding dengan suhu 20 derajat. Perbedaan selisih suhu antara 40 dan 50 derajat nilainya sama dengan perbedaan suhu antara 20 dan 30 derajat, yaitu 10 derajat (Setiawan, 2011).

Peringkat cagar budaya tidak bergerak juga dapat diukur berdasarkan skala interval. Peringkat tersebut terdiri dari peringkat lokal (kabupaten/ kota), peringkat regional (provinsi), dan peringkat nasional (Indonesia). Peringkat 1 (pertama) adalah peringkat lokal yang merupakan peringkat terkecil nilainya antara 16,5\% - 33\%. Peringkat 2 (kedua) adalah peringkat regional yang merupakan peringkat menengah nilainya $33,5 \%-66 \%$. Adapun peringkat 3 (ketiga) adalah peringkat nasional yang merupakan peringkat tertinggi nilainya 66,5\% - 100\%. Selengkapnya dapat dilihat pada Tabel 3. Dari uraian di Tabel 3 jelas, bahwa pada skala interval, selain bisa membedakan (mengkategorikan), mengurutkan nilainya, juga bisa dihitung berapa perbedaannya/ selisihnya dan jarak atau intervalnya juga dapat dibandingkan. Perbedaan antara kedua nilai pada skala interval sudah punya makna yang berarti, berbeda dengan selisih pada skala ordinal yang maknanya tidak berarti. Dengan demikian, selain sudah mencakup skala nominal, juga sudah termasuk skala ordinal, tetapi nilai mutlaknya tidak dapat dibandingkan secara matematik. Oleh karena batasbatas variasi nilai pada interval adalah arbiter (angka nolnya tidak absolut).

\subsection{Variabel Rasio/ Skala Rasio}

Variabel rasio sangat mirip dengan variabel interval; di samping sudah memiliki semua sifat-sifat

Tabel 2. Skala ordinal pemeringkatan cagar budaya

\begin{tabular}{|c|c|c|c|c|c|}
\hline \multirow[t]{2}{*}{ NO } & \multirow[t]{2}{*}{ PARAMETER } & \multirow[t]{2}{*}{ VARIABEL BEBAS } & \multicolumn{3}{|c|}{ VARIABEL TERIKAT DALAM NILAI } \\
\hline & & & 3 & 2 & 1 \\
\hline \multirow{3}{*}{1} & \multirow{3}{*}{ Pemersatu } & Kepemilikan & Negara & Masyarakat adat & Individu \\
\hline & & Cara Perolehan & Pencarian & Pengalihan & Penemuan \\
\hline & & Registrasi & Penetapan & Rekomendasi & Pendaftaran \\
\hline \multirow{3}{*}{2} & \multirow{3}{*}{ Adiluhung } & Penyelamatan & Insitu & Pindah sebagian & Pindah total \\
\hline & & Zonasi & Pengembangan & Penyangga & Inti \\
\hline & & Umur & Absolut & Relatif & Arti khusus \\
\hline \multirow{3}{*}{3} & \multirow{3}{*}{$\begin{array}{l}\text { Kawasan /Lansekap } \\
\text { Budaya, Ruang Khas } \\
\text { Tradisional }\end{array}$} & Pemeliharaan & Perawatan & Konservasi & Pembersihan \\
\hline & & Pengamanan & Jupel/Polsus & Sarana pelindung & Partisipasi publik \\
\hline & & Pengembangan & Ideologi & Akademi & Ekonomi \\
\hline \multirow{3}{*}{4} & \multirow{3}{*}{$\begin{array}{l}\text { Unik Rancangannya/ } \\
\text { Langka/Jumlahnya } \\
\text { Sedikit }\end{array}$} & Pemugaran & Restorasi & Rekonstruksi & Rehabilitasi \\
\hline & & Revitalisasi & Informasi kuat & Fungsi ruang tetap & Budaya \\
\hline & & Adaptasi & $\begin{array}{l}\text { Menambah } \\
\text { fasilitas }\end{array}$ & $\begin{array}{l}\text { Fungsi ruang } \\
\text { berubah }\end{array}$ & $\begin{array}{l}\text { Fasad arsitektur } \\
\text { tetap }\end{array}$ \\
\hline \multirow{3}{*}{5} & Evolusi Peradaban/ & Pemanafaatan & Dokumentasi & Alih fungsi & Perbanyak \\
\hline & Pertukaran Lintas & Pendanaan & APBN/APBD & Pemanfaatan & Sumber lain \\
\hline & Budaya & Pengawasan & Koordinasi & PPNS & Masyarakat \\
\hline
\end{tabular}

Tabel 3. Skala interval pemeringkatan cagar budaya

\begin{tabular}{|llcc} 
No & \multicolumn{1}{c}{ PERINGKAT } & SCORE & NILAI \\
\hline 1 & Peringkat Kab/Kota & $\geq 16,5 \%-33 \%$ & 1 \\
2 & Peringkat Provinsi & $\geq 33 \%-66 \%$ & 2 \\
3 & Peringkat Nasional & $\geq 66 \%-100 \%$ & 3
\end{tabular}


variabel interval, juga sudah bisa diidentifikasi titik nol mutlak, sehingga memungkinkan menyatakan rasio atau perbandingan di antara kedua nilai, misalnya $\mathrm{x}$ adalah dua kali lebih $\mathrm{y}$. Contohnya adalah berat, tinggi, panjang, usia, suhu dalam skala kelvin. Sebagai contoh, berat $\mathrm{A}=70 \mathrm{~kg}$, berat $\mathrm{B}=35 \mathrm{~kg}$, berat $\mathrm{C}=0$ $\mathrm{kg}$. Disini bisa membandingkan rasio, misalnya berat A dua kali berat B. Berat $C=0 \mathrm{~kg}$, artinya $\mathrm{C}$ tidak mempunyai bobot. Angka $O$ di sini jelas dan berarti dan angka 0 menunjukkan nilai 0 mutlak. Kuncinya untuk membedakan antara skala interval dengan rasio adalah diangka 0 , apakah nilai nol tersebut mutlak (berarti) atau tidak (Wijaya : 2004).

Peringkat cagar budaya tidak bergerak juga dapat diukur berdasarkan skala interval. Perbandingan interval antar peringkat adalah $1: 2: 3$. Perbandingan peringkat lokal dan peringkat regional adalah $1: 2$. Dengan kata lain nilai peringkat regional 2 kali peringkat lokal. Perbandingan peringkat lokal dan peringkat nasional adalah $1: 3$. Dengan kata lain peringkat nasional skornya 3 kali lipat peringkat lokal. Sedangkan peringkat yang skornya sama dengan atau kurang dari 16,5 \% tidak termasuk cagar budaya. Artinya peringkat bukan cagar budaya nilainya 0 . Angka 0 di sini jelas dan berarti. Angka 0 menunjukkan nilai 0 mutlak. Selengkapnya periksa Tabel 4.

\subsection{Variabel Kontrol/Skala Kontrol}

Variabel kontrol adalah variabel yang berfungsi sebagai kontrol atau kendali guna menetralisir sehingga data sesuai dengan fakta. Peringkat cagar budaya tidak bergerak juga dapat diukur berdasarkan skala kontrol dengan cara setiap variabel bebas diberi bobot persentase. Dalam menentukan skor ada batasan toleransi yang dibuat. Jika melewati batas toleransi, maka data akan berubah dan tidak lagi sesuai fakta. Selengkapnya periksa Tabel 5.

\subsection{Cara Menghitung}

Aplikasi keempat skala di atas diuji coba pada situs Keraton Surosowan, Banten seperti di bawah

Tabel 4. Skala rasio pemeringkatan cagar budaya

\begin{tabular}{clllll} 
No & \multicolumn{1}{c}{ PERINGKAT } & \multicolumn{1}{c}{ BOBOT } & \multicolumn{1}{c}{ SKOR } & NILAI & \multicolumn{1}{c}{ KETERANGAN } \\
\hline 1 & BUKAN CAGAR BUDAYA & $1 / 3 \times 10 \times 5 \%=16,5 \%$ & $<16,5 \%$ & 0 & Variabel nilai 1, bobot $5 \%$ \\
\hline 2 & TINGKAT KAB/KOTA & $(1 / 3 \times 5 \times 10 \%)+(1 / 3 \times 10 \times$ & $\geq 16,5 \%-$ & 1 & Seluruh variabel nilai 1 \\
& & $5 \%)=33 \%$ & $33 \%$ & & Seluruh variabel nilai 2 \\
3 & TINGKAT PROVINSI & $(2 / 3 \times 5 \times 10 \%)+(2 / 3 \times 10 \times$ & $\geq 33 \%-66 \%$ & 2 & \\
& & $5 \%)=66 \%$ & & Seluruh variabel nilai 3
\end{tabular}

Tabel 5. Skala kontrol pemeringkatan cagar budaya

\begin{tabular}{|c|c|c|c|c|c|c|c|c|}
\hline \multirow[t]{2}{*}{ NO } & \multirow[t]{2}{*}{ VARIABEL BEBAS } & \multicolumn{7}{|c|}{ VARIABEL TERIKAT } \\
\hline & & Bobot & Nilai & Skor & Nilai & Skor & Nilai & Skor \\
\hline 1 & Penentuan umur & $10 \%$ & 3 & \multirow{5}{*}{$10 \%$ s $/ d 7 \%$} & 2 & \multirow{5}{*}{$\begin{array}{c}<7 \% \text { s } / \mathrm{d} \\
3,5 \%\end{array}$} & 1 & \multirow{5}{*}{$\begin{array}{c}<3,5 \% \mathrm{~s} / \mathrm{d} \\
2,5 \%\end{array}$} \\
\hline 2 & Kepemilikan & $10 \%$ & 3 & & 2 & & 1 & \\
\hline 3 & Cara Perolehan & $10 \%$ & 3 & & 2 & & 1 & \\
\hline 4 & Registrasi & $10 \%$ & 3 & & 2 & & 1 & \\
\hline 5 & Penyelamatan & $10 \%$ & 3 & & 2 & & 1 & \\
\hline 6 & Pengamanan & $5 \%$ & 3 & \multirow{11}{*}{$5 \%$ s/d $3,5 \%$} & 2 & \multirow{11}{*}{$\begin{array}{c}<3,5 \% \mathrm{~s} / \mathrm{d} \\
2,5 \%\end{array}$} & 1 & \multirow{11}{*}{$2,5 \%$ s/d $0,5 \%$} \\
\hline 7 & Zonasi & $5 \%$ & 3 & & 2 & & 1 & \\
\hline 8 & Pemeliharaan & $5 \%$ & 3 & & 2 & & 1 & \\
\hline 9 & Pemugaran & $5 \%$ & 3 & & 2 & & 1 & \\
\hline 10 & Pengembangan & $5 \%$ & 3 & & 2 & & 1 & \\
\hline 11 & Revitalisasi & $5 \%$ & 3 & & 2 & & 1 & \\
\hline 12 & Adaptasi & $5 \%$ & 3 & & 2 & & 1 & \\
\hline 13 & Pemanafaatan & $5 \%$ & 3 & & 2 & & 1 & \\
\hline 14 & Pendanaan & $5 \%$ & 3 & & 2 & & 1 & \\
\hline \multirow[t]{2}{*}{15} & Pengawasan & $5 \%$ & 3 & & 2 & & 1 & \\
\hline & Jumlah & $100 \%$ & 45 & & 30 & & 15 & \\
\hline
\end{tabular}


Tabel 6. Hasil pemeringkatan Situs Surosowan, Banten

\begin{tabular}{|c|c|c|c|c|c|}
\hline No & PARAMETER & VARIABEL & ВОВОТ & NILAI & SKOR \\
\hline 1 & 2 & 3 & 4 & 5 & 6 \\
\hline \multirow{3}{*}{1} & \multirow{3}{*}{ Pemersatu } & Kepemilikan & $9 \%$ & 3 & $9 \%$ \\
\hline & & Cara Perolehan & $9 \%$ & 2 & $6 \%$ \\
\hline & & Registrasi & $8 \%$ & 3 & $8 \%$ \\
\hline \multirow{3}{*}{2} & \multirow{3}{*}{ Adiluhung } & Penyelamatan & $8 \%$ & 2 & $5 \%$ \\
\hline & & Zonasi & $4 \%$ & 1 & $1 \%$ \\
\hline & & Umur & $9 \%$ & 3 & $9 \%$ \\
\hline \multirow{3}{*}{3} & \multirow{3}{*}{$\begin{array}{l}\text { Kawasan /Lansekap Budaya, } \\
\text { Ruang Khas Tradisional }\end{array}$} & Pemeliharaan & $2 \%$ & 1 & $1 \%$ \\
\hline & & Pengamanan & $2 \%$ & 2 & $1 \%$ \\
\hline & & Pengembangan & $2 \%$ & 1 & $1 \%$ \\
\hline \multirow{3}{*}{4} & \multirow{3}{*}{$\begin{array}{l}\text { Unik Rancangannya/ Langka/ } \\
\text { Jumlahnya Sedikit }\end{array}$} & Pemugaran & $3 \%$ & 3 & $3 \%$ \\
\hline & & Revitalisasi & $4 \%$ & 3 & $4 \%$ \\
\hline & & Adaptasi & $3 \%$ & 2 & $2 \%$ \\
\hline \multirow{5}{*}{5} & \multirow{3}{*}{$\begin{array}{l}\text { Evolusi Peradaban/ Pertukaran } \\
\text { Lintas Budaya }\end{array}$} & Pemanafaatan & $4 \%$ & 3 & $4 \%$ \\
\hline & & Pendanaan & $4 \%$ & 3 & $4 \%$ \\
\hline & & Pengawasan & $4 \%$ & 3 & $4 \%$ \\
\hline & & & & Jumlah & $62 \%$ \\
\hline & & & Peringk & & \\
\hline
\end{tabular}

ini. Secara umum situs Keraton Surosowan dikenal sebagai situs nasional. Akan tetapi secara de facto situs ini telah mengalami degradasi, sehingga peringkatnya berubah. Dalam melakukan scoring kondisi eksisting menjadi pertimbangan utama, sehingga penilaiannya dapt dilihat di Tabel 6.

Berdasarkan hasil penilaian pada tabel, tampak bahwa tidak ada bobot yang optimal (dalam persentase). Hal ini terjadi akibat kondisi eksisting situs Surosowan yang masih jauh dari upaya pelestarian. Secara umum kondisi eksisting situs Surosowan berdasarkan variabel-variabel tersebut di atas dapat dikemukakan sebagai berikut:

1. Situs Keraton Surosowan secara kepemilikan adalah milik negara, akan tetapi bukti keaslian berupa sertifikat tanah dan bangunan sebagai milik negara tidak ada, maka bobot kepemilikan kurang dari $10 \%$;

2. Situs Keraton Surosowan secara zonasi baru dapat ditentukan zona inti, akan tetapi kepastian zona inti dengan batas-batasnya belum ditentukan secara legal, maka bobot zonasi di bawah $5 \%$;

3. Situs Keraton Surosowan dalam hal pengamanan ada partisipasi publik akan tetapi bukti bahwa partisipasi publik tersebut berdampak positif tidak signifikan, maka bobot pengamanan kurang dari $5 \%$;

4. Situs Keraton Surosowan pernah dipugar/ direstorasi, akan tetapi bukti keaslian bangunan tidak otentik, maka bobot pemugaran kurang dari $5 \%$;

5. Situs Keraton Surosowan dalam hal pengawasan tampak bahwa negara melibatkan masyarakat. Akan tetapi peran masyarakat/ partisipasi publik tersebut tidak signifikan, bahkan cenderung merusak, sehingga bobot pengawasan kurang dari $5 \%$;

6. Dan seterusnya.

\section{PENUTUP}

Pemeringkatan merupakan bagian dari proses registrasi cagar budaya. Jelasnya, sebelum melakukan pemeringkatan terlebih dahulu melakukan pendaftaran. Tahap selanjutnya melakukan klasifikasi dan identifikasi cagar budaya. Langkah ketiga melakukan penilaian atau pemeringkatan. Pemeringkatan ini menghasilkan rekomendasi 
tentang peringkat cagar budaya, yang selanjutnya ditindaklanjuti dengan penetapan oleh kepala daerah dan/atau menteri sesuai dengan peringkatnya. Output serangkaian kegatan ini adalah dimasukkannya cagar budaya dalam daftar registrasi nasional.

Ada dua kategori variabel yang harus dibuat, yaitu variabel penyebab dan variabel akibat. Variabel penyebab dikenal dengan variabel bebas atau variabel faktor, sedang variabel akibat adalah variabel terikat (respons). Jumlah keseluruhan variabel bebas sebanyak 15 variabel. Adapun keseluruhan variabel respon berjumlah 45 variabel. Kedua jenis variabel di atas dapat dibedakan menjadi peringkat lokal (kabupaten/ kota), peringkat regional (provinsi), dan peringkat nasional. Untuk menentukan peringkat ini dibentuk tim ahli cagar budaya yang ditetapkan oleh gubernur,

\section{Daftar Pustaka}

Antoso. 2004. SPSS Versi 10 Mengolab data Statistik Secara Profesional. Jakarta: Elex Media Komputindo.

Gunawan, Fransiskus, 2010. Skala Pengukuran Varwiabel (www.scribd.com).

Hasan, I. (2005). Pokok - Pokok Materi Statistik 1, Edisi kedua. Jakarta : PT. Bumi Aksara.

Kemendikbud. 2013. Undang-undang Nomor 11 Tabun 2010 tentang Cagar Budaya. bupati/walikota dan atau menteri.

Tugas tim ahli adalah melakukan penilaian dan rekomendasi peringkat cagar budaya. Berdasarkan rekomendasi tim, cagar budaya dapat dikategorikan dalam 3 (tiga) peringkat. Peringkat 1 merupakan peringkat kabupaten/kota yang nilainya antara 16,5\% - 33\%. Peringkat 2 merupakan peringkat regional yang nilainya $33,5 \%$ - 66\%. Adapun peringkat 3 merupakan peringkat nasional yang nilainya $66,5 \%$ $100 \%$. Kondisi cagar budaya bersifat dinamis, artinya sewaktu-waktu mengalami perubahan. Demikian juga peringkat cagar budaya juga bersifat dinamis, mengikuti perubahan cagar budaya itu sendiri.

Sutrisno, Hadi. 1987. Statistik Jilid I. Yogyakarta: Fakultas Psikologi UGM.

Setiawan, Ade. 2011. Statistika Dasar (www. smartstat). Penjagahati. 2011. Pengertian Variabel dan Jenis-Jenis (www.zone.blogspot. com).

Wijaya, Awi Muliadi. 2010. Skala Pengukuran (www. indokterku.com). 